\title{
Religious Harmony Among Multi-Religious society in Perak, Malaysia: A Preliminary Study
}

\author{
Mohd Ikhwan Izzat Zulkefli ${ }^{I^{*}}$, Mohd Nuri Al-Amin Endut ${ }^{1}$, and Muhammad Ridhuan Tony \\ Lim Abdullah ${ }^{l}$ \\ ${ }^{1}$ Department of Management and Humanities, Universiti Teknologi PETRONAS, 32610 Bandar Seri \\ Iskandar, Perak, Malaysia
}

\begin{abstract}
Religious harmony between different religious adherents is important in determining social peace and harmony in a plural country like Malaysia. The failure to ensure religious harmony can disrupt political and national stability. Hence, all parties, including policy makers, religious leaders and society should work together to strengthen inter-religious relations. The purpose of this study is to measure the level of religious harmony in Perak. It used a survey questionnaire as an instrument for data collection in which data from a total of 44 respondents were analysed using Statistical Package for Social Sciences (SPSS) version 24.0 software. The findings generally revealed that all dimensions of religious harmony were at a moderately high level. Surprisingly, the findings also showed that 'Understanding', 'Cooperation' and 'Stable Conflict' were recorded as the highest mean score for the Hindu group, while 'Peacefulness', Acceptance', 'Understanding', and 'Right and Justice' were recorded as the lowest mean score for the Buddhist group. The study offers a valid measurement to determine the level of religious harmony that will advise the government to take appropriate measures to mitigate religious conflict and promote mutual understanding within multi-religious society.
\end{abstract}

Keywords: Religion, harmony, multi-religious society, preliminary study, Perak

\section{Introduction}

Religious harmony is not a new issue that has been raised in many countries, especially countries consist of different ethnic and religious groups. This issue has become a major concern of many leaders of countries to ensure and maintain religious harmony. The growing number of religious conflicts in various parts of the world has shown that religious issues are sensitive issues that could interrupt inter-religious relations. According to Syihab and Muhamad (2017), conflicts and disagreements have been part of human interaction since ancient time. Meanwhile, Engineer (1990) argues that religion has become one of the contributing factors to conflicts and bloodshed in the modern era, particularly in the third world countries. Hence, strengthening of inter-religious relations is one of the most

\footnotetext{
* Corresponding author: ikhwanmuslimin92@gmail.com
} 
important instruments for maintaining stability in the country. It is also essential to foster harmony in order to bring together multi-religious and multi-racial society to contribute to the prosperity of the country. However, with the existence of the diversity of religions and ethnicities in the country, it is very difficult to ensure harmony and peaceful coexistence (Sintang, 2014; Sintang, Baharuddin, \& Khambali@ Hambali, 2012).

Similar to the global scenario, after the incident of the "May 13 riots", Malaysia is still facing major and minor incidents, especially in the issue of inter-religious relations. Even though Malaysia appears to be a peaceful country, the existence of various religious conflicts has a great potential to interrupt political and national stability (Abdullah et al., 2016). Nowadays, the maintenance of social peace and harmony in a multi-religious society of Malaysia has become more complex in the face of religious issue (Sintang, 2014). Based on previous studies, the place of worship, the right to custody of children (Ahmad et al., 2014) and the issue of kalimah Allah which can be used by non-Muslims (Nor, 2011; Yasin, 2019) are among sensitive issues that could undermine religious harmony. Apart from that, the use of Qur'anic and Arabic terminologies, Islamic propagation, funeral process, the halal certificate used by a non-Muslim businessman and many other sensitive issues also could interrupt the peaceful coexistence in a Malaysian society (Sintang et al., 2012).

Furthermore, the incidents of religious conflicts were noted through several cases. For instance, in 1998, an incident involving Muslims and Hindus on the issue of interrupting prayer time in Kampung Rawa (Shukri, 2004). This incident resulted in numerous bloodsheds and destruction of properties (Shukri, 2004). Besides that, on August 28, 2009, an incident involving Muslims and Hindus took place in Shah Alam, Selangor (Fong \& Kit, 2017). This issue is related to the demonstration of the Cow Head. The purpose of the demonstration was to prevent the relocation of the Hindu temple in Section 23, Shah Alam due to the Muslim-majority area (Fong \& Kit, 2017).

To address the issue of inter-religious harmony, many improvements and initiatives have been implemented for the betterment of the Malaysian nation. The recent initiatives taken by the government amongst others, is the declaration of Shared Prosperity Vision 2030 (Wawasan Kemakmuran Bersama 2030). The goal of this vision is "to provide a decent standard of living to all Malaysian by 2030" (Shared prosperity vision 2030: Restructuring the priorities of Malaysia's development, 2019). The main focus of this vision is also to build a unified nation of Malaysia (Shared prosperity vision 2030: Restructuring the priorities of Malaysia's development, 2019). In addition to that, among the other initiatives implemented by the government to strengthen national unity are the introduction of New Economic Policy (NEP), the National Cultural Policy, the National Education Policy, the National Language Policy, Vision 2020, and Concept of 1 Malaysia (Shamsuddin, Liaw, \& Ridzuan, 2015). Besides that, the formation of Institute for Ethnic Studies (KITA) in Universiti Kebangsaan Malaysia (UKM), the Department of National Unity of Integration (JPNIN) (Abdullah, Al-Amin, Ur-Rahman, Baharuddin, \& Ahmad, 2017), the celebration of religious festivals (Abubakar, 2013) and many other efforts. Moreover, in order to preserve inter-religious relations, the government has formed a special committee under JPNIN, namely Committee to Promote Understanding and Harmony Religious Adherents (JKMPKA). The main function of JKMPKA is to complement government efforts to promote understanding and harmony among religions in Malaysia (Abdullah et al., 2017).

This study is intended to present the status of religious harmony among multi-religious society in Perak. Therefore, this study has the following two objectives:

1. To identify the level of the dimensions of religious harmony.

2. To determine the level of the dimensions of religious harmony according to the religious group. 
This paper is organised in the following sections. The first section explains the background and issues of religious harmony. The second section describes the methodology used in this study. Next, the third section presents the results and findings of the study. Finally, the last section elaborates the discussion of the results.

\section{Methodology}

This is a quantitative study and the data presented in this paper were generated from the preliminary study. The instrument of this study consisted of two main sections, namely Section A: demographic information and Section B: dimensions of religious harmony. For Section B, each respondent had to answer the questionnaire based on 5-point Likert scale ranging from 1 (strongly disagree) to 5 (strongly agree). This study was carried out through a survey to obtain the response of the multi-religious society in Perak. The respondents of this study involved four main religious adherents in Perak, namely Muslims, Buddhists, Hindus and Christians.

In this preliminary study, 50 questionnaires were distributed to respondents residing in the Kinta district. However, only 44 questionnaires were analysed in the IBM Statistical Package for Social Sciences (SPSS) version 24.0. The remaining six questionnaires were excluded due to the straight lines in the questionnaire response. According to Memon, Ting, Ramayah, Chuah, and Cheah (2017), a sample of 30 people is usually supported for a pilot study. In the same stance, Cooper and Schindler (2011) also pointed out that a range between 25 and 100 individuals is appropriate for a pilot study.

The collected data were then analysed using Statistical Package for Social Sciences (SPSS) version 24.0. This study mainly used descriptive analyses to obtain mean, standard deviation, frequency and percentage. Prior to that, the reliability test of the items constituting the dimensions was measured using Cronbach's alpha to check the internal consistency (Memon et al., 2017). As shown in Table 1, all six dimensions had a Cronbach alpha scores threshold value above 0.70 , which is considered as valid and acceptable (Namdeo \& Rout, 2016). Hence, all the items constituting the dimensions have been retained.

Table 1. Result of reliability.

\begin{tabular}{|c|c|c|}
\hline Dimensions & Number of Items & Cronbach Alpha \\
\hline Peacefulness & 8 & 0.808 \\
\hline Acceptance & 6 & 0.775 \\
\hline Understanding & 9 & 0.838 \\
\hline Co-operation & 14 & 0.894 \\
\hline Right \& Justice & 5 & 0.822 \\
\hline Stable Conflict & 13 & 0.955 \\
\hline
\end{tabular}

Apart from that, the descriptive analysis also was analysed to obtain the mean score. Mean score interpretation was classified into four categories: low (1.00-2.00), moderately low (2.01-3.00), moderately high (3.01-4.00) and high (4.01-5.00). 
Table 2. Interpretation of the Mean Score (Harun, Salleh, Memon, Baharom, \& Abdullah, 2014).

\begin{tabular}{|c|c|}
\hline Mean Score & Interpretation \\
\hline $1.00-2.00$ & Low \\
\hline $2.01-3.00$ & Moderately low \\
\hline $3.01-4.00$ & Moderately high \\
\hline $4.01-5.00$ & High \\
\hline
\end{tabular}

\section{Results and Findings}

This section presents the demographic profile of the respondents, the level of the dimensions of religious harmony and the level of the dimensions of religious harmony according to the religious group. These findings were analysed descriptively using SPSS version 24 software.

\subsection{Demographic Profile of the Respondents}

Table 1 illustrates the demographics of the respondent in the study. This demographic information including gender, age, religion, ethnic, academic qualification and area of residence. The profile depicts that the number of respondents in this study was approximately 44 respondents. Of the 44 samples, the majority of respondents were female $(61.4 \%)$ and male $(38.6 \%)$. As for the age, respondents were divided into four categories: 19 respondents $(43.2 \%)$ aged between 18 and 29 years, 12 respondents $(27.2 \%)$ aged between 30 and 39 years, 9 respondents (20.5\%) aged between 40 and 49 years, and 4 respondents $(9.1 \%)$ aged 50 years and above. The majority $(43.2 \%)$ were aged between 18 and 29 years old. With regard to religious background, the findings revealed that the majority of the respondents were Muslim (56.8\%), Buddhist (22.7\%), Hindu (15.9\%) and Christian (4.5\%). Meanwhile, in terms of ethnicity, Malays represented $56.8 \%$ of respondents, Chinese $(22.7 \%)$, Indians $(18.2 \%)$ and others $(2.3 \%)$. Furthermore, the respondents were also asked about their academic qualifications. This study shows that the majority of the respondents have STPM/ STP/ HSC/ 'A' LEVEL/ I.B./ STAM/ Matric (47.7\%), followed by SPM/ MCE/ SC/ 'O' LEVEL/ SMA/ SPVM (18.2\%), Degree $(15.9 \%)$, others $(15.9 \%)$ and Certificate $(2.3 \%)$. Finally, the findings also revealed that the largest number of respondents lived in city (59.1\%), suburb (36.4\%) and rural area $(4.5 \%)$.

Table 3. Demographic profile of respondents.

\begin{tabular}{|l|l|c|c|}
\hline Variables & \multicolumn{1}{|c|}{ Category } & Frequency & Percent \\
\hline \multirow{3}{*}{ Gender } & Male & 17 & 38.6 \\
\cline { 2 - 5 } & Female & 27 & 61.4 \\
\hline \multirow{3}{*}{ Age } & $18-29$ & 19 & 43.2 \\
\cline { 2 - 5 } & $30-39$ & 12 & 27.2 \\
\cline { 2 - 5 } & $40-49$ & 9 & 20.5 \\
\hline
\end{tabular}




\begin{tabular}{|c|c|c|c|}
\hline & $50>$ & 4 & 9.1 \\
\hline \multirow[t]{4}{*}{ Religion } & Islam & 25 & 56.8 \\
\hline & Buddhism & 10 & 22.7 \\
\hline & Hinduism & 7 & 15.9 \\
\hline & Christianity & 2 & 4.5 \\
\hline \multirow[t]{4}{*}{ Ethnic } & Malay & 25 & 56.8 \\
\hline & Chinese & 10 & 22.7 \\
\hline & Indian & 8 & 18.2 \\
\hline & Others & 1 & 2.3 \\
\hline \multirow{5}{*}{$\begin{array}{l}\text { Academic } \\
\text { Qualificatio } \\
-n\end{array}$} & SPM/MCE/SC/'O' LEVEL/SMA/SPVM & 8 & 18.2 \\
\hline & STPM/STP/HSC/'A'LEVEL/I.B./STAM/Matric & 21 & 47.7 \\
\hline & Certificate & 1 & 2.3 \\
\hline & Degree & 7 & 15.9 \\
\hline & Others & 7 & 15.9 \\
\hline \multirow{3}{*}{$\begin{array}{l}\text { Area of } \\
\text { Residence }\end{array}$} & City & 26 & 59.1 \\
\hline & Suburb & 16 & 36.4 \\
\hline & Rural & 2 & 4.5 \\
\hline
\end{tabular}

\subsection{The Level of the Dimensions of Religious Harmony}

The overall mean score for each dimension was obtained to identify the level of the dimension of religious harmony in Perak. As presented in Table 4, the mean value ranges from 3.386 to 3.915 , which is considered moderately high. The findings revealed that the three highest dimensions of the religious harmony in this study were 'Peacefulness' (Mean = 3.915; $\mathrm{SD}=0.478)$, 'Acceptance' (Mean = 3.846; $\mathrm{SD}=0.454)$, 'Understanding' (Mean = 3.846; SD $=0.504)$. Meanwhile, the remaining dimensions of religious harmony were 'Cooperation' (Mean = 3.797; $\mathrm{SD}=0.503$ ), 'Right and Justice' $($ Mean $=3.655$; SD = 0.632 ) and 'Stable Conflict' (Mean $=3.386 ; \mathrm{SD}=0.713$ ). This indicated that 'Peacefulness' received the highest mean score compared to other dimensions of religious harmony in the context of Perak. 
Table 4. Distribution of mean and standard deviation.

\begin{tabular}{|l|c|c|c|}
\hline \multicolumn{1}{|c|}{ Dimensions } & Mean & Std. Deviation & Interpretation \\
\hline Peacefulness & 3.915 & 0.478 & Moderately high \\
\hline Acceptance & 3.879 & 0.454 & Moderately high \\
\hline Understanding & 3.846 & 0.504 & Moderately high \\
\hline Cooperation & 3.797 & 0.503 & Moderately high \\
\hline Right \& Justice & 3.655 & 0.632 & Moderately high \\
\hline Stable Conflict & 3.386 & 0.713 & Moderately high \\
\hline
\end{tabular}

\subsection{The Level of the Dimensions of Religious Harmony According to the Religious Group}

Table 5 exhibits the distribution of the mean score of the dimensions of religious harmony according to the different religious groups. The findings indicated that the level of the mean score for the dimensions of religious harmony which ranges from 2.846 to 4.333 , based on a five-point Likert scale ranging from $1=$ Strongly Disagree to $5=$ Strongly Agree. This showed that the mean score for all dimension is between moderately low and high.

As shown in Table 5, the findings revealed that three dimensions of religious harmony obtained the highest mean value recorded for the Hindu group. These dimensions are 'Understanding' $($ Mean $=4.206 ; \mathrm{SD}=0.392)$, 'Cooperation $($ Mean $=4.102 ; \mathrm{SD}=0.387)$ and 'Stable Conflict' (Mean $=3.791$; $\mathrm{SD}=0.515$ ). The findings also unveiled that the highest mean score of 'Peacefulness' (Mean $=4.040 ; \mathrm{SD}=0.453)$ and 'Right and Justice' (Mean $=3.776 ; \mathrm{SD}=0.598$ ) was recorded for the group of Muslims. Only 'Acceptance', the Christian group obtained the highest mean value with a score of $4.333(\mathrm{SD}=0.943)$.

On the other hand, the findings showed that four dimensions of religious harmony scored the lowest mean value for the Buddhist group. These dimensions are 'Peacefulness' $($ Mean $=3.550 ; \mathrm{SD}=0.514)$, Acceptance' $($ Mean $=3.633 ; \mathrm{SD}=0.367)$, 'Understanding' $($ Mean $=3.633 ; \mathrm{SD}=0.422)$, and 'Right and Justice' (Mean = 3.300; SD =0.818). While, the Christian group also scored two dimensions of religious harmony with the lowest mean score. These dimensions are 'Cooperation' (Mean $=3.464 ; \mathrm{SD}=0.253$ ) and 'Stable Conflict' $($ Mean $=2.846$; $\mathrm{SD}=0.218$ ).

Therefore, based on the overall findings, the analysis found that the group of Hindus obtained the highest mean value for three dimensions, namely Peacefulness, Understanding and Cooperation. On the other hand, the group of Buddhists scored the lowest mean value for the dimensions of Peacefulness, Acceptance, Understanding and Right and Justice. 
Table 5. Distribution of mean and standard deviation according to religious group.

\begin{tabular}{|c|c|c|c|c|}
\hline Dimensions & Category & $\mathbf{N}$ & Mean & Std. Deviation \\
\hline \multirow{5}{*}{ Peacefullness } & Islam & 25 & 4.040 & 0.453 \\
\hline & Buddhism & 10 & 3.550 & 0.514 \\
\hline & Hinduism & 7 & 4.018 & 0.293 \\
\hline & Christianity & 2 & 3.812 & 0.442 \\
\hline & Total & 44 & 3.915 & 0.478 \\
\hline \multirow{5}{*}{ Acceptance } & Islam & 25 & 3.993 & 0.383 \\
\hline & Buddhism & 10 & 3.633 & 0.367 \\
\hline & Hinduism & 7 & 3.691 & 0.522 \\
\hline & Christianity & 2 & 4.333 & 0.943 \\
\hline & Total & 44 & 3.879 & 0.454 \\
\hline \multirow{5}{*}{ Understanding } & Islam & 25 & 3.809 & 0.498 \\
\hline & Buddhism & 10 & 3.633 & 0.422 \\
\hline & Hinduism & 7 & 4.206 & 0.392 \\
\hline & Christianity & 2 & 4.111 & 0.943 \\
\hline & Total & 44 & 3.846 & 0.504 \\
\hline \multirow{5}{*}{ Cooperation } & Islam & 25 & 3.806 & 0.545 \\
\hline & Buddhism & 10 & 3.629 & 0.430 \\
\hline & Hinduism & 7 & 4.102 & 0.387 \\
\hline & Christianity & 2 & 3.464 & 0.253 \\
\hline & Total & 44 & 3.797 & 0.503 \\
\hline \multirow{6}{*}{ Right and Justice } & Islam & 25 & 3.776 & 0.598 \\
\hline & Buddhism & 10 & 3.300 & 0.818 \\
\hline & Hinduism & 7 & 3.714 & 0.380 \\
\hline & Christianity & 2 & 3.700 & 0.141 \\
\hline & Total & 44 & 3.655 & 0.632 \\
\hline & Islam & 25 & 3.348 & 0.735 \\
\hline
\end{tabular}




\begin{tabular}{|l|l|c|c|c|}
\hline \multirow{4}{*}{ Stable Conflict } & Buddhism & 10 & 3.308 & 0.776 \\
\cline { 2 - 5 } & Hinduism & 7 & 3.791 & 0.515 \\
\cline { 2 - 5 } & Christianity & 2 & 2.846 & 0.218 \\
\cline { 2 - 5 } & Total & 44 & 3.386 & 0.713 \\
\hline
\end{tabular}

\section{Discussion}

The first objective of this study is to identify the level of the dimensions of religious harmony. On the whole, the findings of this study indicate that the mean score for all dimensions of religious harmony in Perak is moderately high (Table 4). Out of these six dimensions studied, 'Peacefulness' was identified as the highest level of the dimension of religious harmony with a mean score of $3.915(\mathrm{SD}=0.478)$. In the case of this study, the respondents have the feeling of always living in a peaceful environment. This shows that the plural society in Perak lives in a peaceful environment despite the state having different religious groups. According to Hung (2014), Malaysians are generally peace-loving people, although inter-ethnic or inter-religious relations have generally been deemed to have worsened over the decades. As proposed by Gordon, the effect of ethnic interaction in one circumstance (i.e., good environmental conditions) would improve the quality of contact (Zainal \& Salleh, 2010). The minority groups such as Buddhists and Hindus should assimilate with main religious group namely Muslims to establish good environmental conditions.

In addition, the findings also showed that 'Acceptance' was recorded as the second highest level of mean score. The respondents agree that the society in Perak can accept the existence of other religious adherents. The openness to accept the presence of different religious adherents could also be linked to the spirit of tolerance that has been inculcated in their religions and society. The acceptance of diversity in the community has become a foundation of the unity which has established social consolidation as well as prosperity in the neighbourhood (Jayasooria \& Raj, 2019). The findings of this study are broadly in line with Talib, Aziz, Kamarulzaidi, and Xue (2019) who found that the level of peacefulness, acceptance and understanding within multi-religious society in the Malaysian context was at a high level. The acceptance of religious diversity in a community is crucial for national unity and harmony (Talib, Gill, \& Ramli, 2014).

Interestingly, despite the high mean value recorded for 'Peacefulness', 'Acceptance', 'Understanding', the findings showed that 'Stable Conflict' received the lowest mean value compared to the other dimensions. This indicates that the respondents believe that religious tensions still exist within Perak's society. In fact, in the case of religious harmony in Perak, the findings seem to suggest that conflicts still exist even though the government has implemented various efforts to strengthen inter-religious relations. This is because the conflict will always be present as long as there are differences in terms of social identity, distribution of resources, interest and ideologies (Suyanto, 2016). The religious conflict can occur in various ways, such as tongue wagging, provocation, religious sentiments (Sintang, 2014), stereotype, provocation and discrimination (Seok et al., 2013). Zainal and Salleh (2010) highlighted that prejudice and stereotype may also occur between inter-religious groups due to the segregation of the education system from the early years of primary education. This segregation could potentially breed others social problems for the future. 
The second objective of this study is to determine the level of the dimensions of religious harmony according to the religious group. The findings unveiled that the group of Hindus, Muslims and Christians obtained the highest mean value for the dimensions of religious harmony. The Hindu group scored the highest mean value for 'Understanding', 'Cooperation' and 'Stable Conflict'. Meanwhile, Muslim scored the highest mean value for 'Peacefulness' as well as 'Right and Justice', and Christian scored the highest mean value for 'Acceptance'. These findings confirm that Hindus, Muslims and Christians have a different view on religious harmony in Perak. For the group of Hindus, they believe that the multi-religious adherents of Perak have strong mutual understanding, cooperation and religious conflict in a stable situation.

In the case of mutual understanding, Hindus agreed that multi-religious groups in Perak have good mutual understanding. Mutual understanding between religious adherents can be achieved when they have good social interaction with one another. According to Nordin, Alias, and Siraj (2018), bringing all religious groups together will lead to interracial contact, which will lead to a better understanding of other races or religious groups and promote greater tolerance and social interaction. In the Malaysian context, leaders of every religious group are working together to raise the level of understanding with the adoption of government policies aimed at building a united Malaysian race alongside parochial and racist (Ramli \& Jamaludin, 2012).

Meanwhile, for Muslims, although they are different from Hindus in terms of belief and practices, they agreed that peacefulness as well as right and justice in Perak is high. Based on the findings, Muslims found that the right and justice towards all religious adherents in the context of Perak is at satisfactory level. All religious adherents have the equal right to profess and practise their religions. This is reflected in the Malaysian government policy regarding official public holidays allowing Malaysian religious citizens to celebrate their main festivals, such as Muslims, Buddhist, Hindus and Christians (Abubakar, 2013). In addition, this is also consistent with the provisions of Article 11 (1) of the Federal Constitution according to which, although Islam is recognised as the Federal religion, other religions may continue to be practiced without interference, provided that they do not cause provocation and affect public order (Meerangani et al., 2021).

\section{Conclusion}

In general, this study identified the level of the dimensions of religious harmony. At the same time, this study also determined the level of the dimensions of religious harmony according to religious group. The findings of this study indicates that all dimension of religious harmony is moderately high. 'Peacefulness' was found to be the highest level of the dimension of religious harmony and this shows that multi-religious society in Perak lives in a peaceful environment. Another major finding of the study is that "Stable Conflict' was recorded the lowest level of the dimensions for the Christian group. This study not only shows the current level of religious harmony, but also provides the level of religious harmony according to religious groups in Perak.

Notwithstanding, as with other studies, this study also has several limitations. Firstly, the findings of this study are based on data from a preliminary study that was collected from 44 multi-religious adherents in Perak, Malaysia. Although the sample size is relatively small, but it can provide an insight and early description of the situation of religious harmony in Perak. Future research could be collected from a larger sample size, which would help to reaffirm the findings of the study. Secondly, the findings of the present study are based on data collected from the multi-religious society in Perak. As such, the generalisability of the findings to other states or countries should be done with caution due 
to the different geopolitical and religious demographics. Future research could also be conducted in other states in Malaysia. Thirdly, this study focuses on four main religious adherents in Perak, namely Muslims, Buddhists, Hindus and Christians. Future research could also explore all religious groups in Perak that could provide the perceptions of religious harmony from their views.

\section{References}

Abdullah, M. R. T. L., Al-Amin, M. N., Ur-Rahman, A., Baharuddin, A., \& Ahmad, Z. (2017). Sustainable socio-religious harmony development in Malaysia: An interpretive structural modelling for multi-religious society Journal of AlTamaddun, 12(1), 53-64.

Abdullah, M. R. T. L., Al-Amin, M. N., Yusoff, A., Baharuddin, A., Khir, F. A., \& Talib, A. T. (2016). Socio-religious harmony index instrument indicators for Malaysia. Journal of Al-Tamaddun, 11(2), 29-44.

Abubakar, I. (2013). The religious tolerance in Malaysia: An exposition. Advances in Natural and Applied Sciences, 7(1), 90-97.

Ahmad, Z., Talib, A. T., Isa, N. A. M., S.Gill, S., Jawan, J., \& Mohad, A. H. (2014). Tahap kepentingan isu-isu antara agama di Malaysia Paper presented at the Seminar Antarabangsa Dakwah \& Etnik 2014: Da'wah \& Ethnicity: Multidisciplinary Perspective, Pusat Kajian Dakwah Orang Asli dan Pribumi, UKM, Bangi, Selangor.

Cooper, D. R., \& Schindler, P. S. (2011). Business research methods. (11 ed.). New York: McGraw-Hill.

Engineer, A. A. (1990). Harmony in a multi-religious society: An Islamic view. New Blackfriars, 71(835), 86-93.

Fong, Y. L., \& Kit, L. W. (2017). Framing the cow-head protest: A comparative analysis of The Star and Malaysiakini. SEARCH: The Journal of the South East Asia Research Centre for Communications and Humanities, 9(1), 71-96.

Harun, H., Salleh, R., Memon, M. A., Baharom, M. N. R., \& Abdullah, A. (2014). Job satisfaction, organizational commitment and stress among offshore Oil and Gas platform employees. Asian Social Science, 10(11), 28-32.

Hung, H. T. M. (2014). Social cohesion in Malaysia. In W. Hofmeister \& P. Rueppel (Eds.), Social Cohesion Addressing Social Divides in Europe and Asia (pp. 59-74). Singapore: Konrad Adenauer Foundation.

Jayasooria, D., \& Raj, J. R. (2019). Kajian berasaskan pengalaman: Pengasasan kejiranan komuniti bandar, kesepaduan sosial dan kualiti kehidupan. Jurnal PERPADUAN, 5, 24-49.

Meerangani, K. A., Sharif, D., Ramli, M. A., Hamid, M. F. A., Zulkefli, A. A., \& Rafie, A. (2021). Tasyabbuh in plural society in Malaysia: An Islamic perspective. International Journal of Academic Research in Business and Social Sciences, 11(8), 1207-1219

Memon, M. A., Ting, H., Ramayah, T., Chuah, F., \& Cheah, J. H. (2017). A review of the methodological misconceptions and guidelines related to the application of structural equation modeling: A Malaysian scenario. Journal of Applied Structural Equation Modeling, 1(1), i-xiii.

Namdeo, S. K., \& Rout, S. D. (2016). Calculating and interpreting Cronbach's alpha using Rosenberg assessment scale on paediatrician's attitude and perception on self esteem. International Journal of Community Medicine and Public Health, 3(6), 1371-1374. 
Nor, M. R. M. (2011). Religious tolerance in Malaysia: An overview. Middle-East Journal of Scientific Research, 9(1), 23-27.

Nordin, A. B., Alias, N., \& Siraj, S. (2018). National integration in multicultural school setting in Malaysia. MOJES: Malaysian Online Journal of Educational Sciences, $1(1), 20-29$.

Ramli, M. A., \& Jamaludin, M. A. (2012). Interaction of plural society in Malaysia: Diatribe or dialogue. Journal World Journal of Islamic History and Civilization, 2(1), 53-57.

Seok, C. B., Mutang, J. A., Madlan, L., Zhi, A. C. H., Joseph, A., Joo, H. C., . . . Baharuddin, S. A. (2013). The perception of characteristics, behaviors, cultures and traditions towards own and other ethnic groups. International Journal of Asian History, Culture and Tradition, 1(1), 1-10.

Shamsuddin, K. A., Liaw, J. O. H., \& Ridzuan, A. A. (2015). Malaysia: Ethnic issues and national security. International Journal of Humanities and Social Science, 5(1), 136-143.

Shared prosperity vision 2030: Restructuring the priorities of Malaysia's development. (2019). Kuala Lumpur: Percetakan Nasional Malaysia Berhad Retrieved from https://www.pmo.gov.my/2019/10/shared-prosperity-vision-2030-2/.

Shukri, A. S. M. (2004). Religions tension and tolerance in Malaysia: A survey of newspaper report incidents from 1997-2003. TAFHIM: IKIM Journal of Islam and the Contemporary World, 1(3), 19-43.

Sintang, S. (2014). Peaceful co-existence in religious diversity in Sabah, Malaysia. Global Journal of Human-Social Science Research, 14(1).

Sintang, S., Baharuddin, A., \& Khambali@ Hambali, K. M. (2012). Dialogue of life and its significance in inter-religious relation in Malaysia. International journal of Islamic thought, 2, 69-79.

Suyanto, B. (2016). Potential threats to social harmony in Johor, Malaysia. Pertanika Journal of Social Sciences \& Humanities, 24(4), 1737 - 1751.

Syihab, A. H., \& Muhamad, A. (2017). Reviving the Wasatiyyah values for inter-religious harmony in plural societies Journal of Al-Tamaddun, 12(2), 13-24.

Talib, A. T., Aziz, E. A., Kamarulzaidi, M. A., \& Xue, F. Y. (2019). Indeks keharmonian sosio-agama di Malaysia. Jurnal PERPADUAN(5), 6-21.

Talib, A. T., Gill, S. S., \& Ramli, M. R. (2014). Pengaruh agama terhadap identiti politik: Kajian kes belia di Malaysia. Paper presented at the Seminar on National Resilience: Diversity in Creating Unity, Premiera Hotel Kuala Lumpur.

Yasin, S. M. (2019). Existing framework of inter-religious dialogue in Malaysia. $A L$ ITQAN: JOURNAL OF ISLAMIC SCIENCES AND COMPARATIVE STUDIES, 2(2), 93-123.

Zainal, K., \& Salleh, N. M. (2010). Ethnic relation among the youth in Malaysia: Toward fulfilling the concept of one Malaysia. Procedia-Social and Behavioral Sciences, 9, 855-858. 